\title{
MORPHOLOGICAL NERVOUS CHANGES IN SURVIVORS OF SEVERE JAUNDICE OF THE NEWBORN
}

\author{
BY \\ L. CROME \\ From the Neuropathology Department, the Fountain Hospital, London
}

The clinical sequelae of $\mathrm{Rh}$ sensitization have been fully described by Pentschew (1948), Pickles (1949), and Evans and Polani (1950). The clinical variability of the condition is well known, but it tends to follow, nevertheless, a certain pattern. A stormy neonatal period with jaundice, drowsiness, feeding difficulties, opisthotonos, and respiratory disturbances is usually followed between the ages of 1 and 2 years by a "silent" period. After that, rigidity, intermittent opisthotonos, and involuntary movements make their appearance. Hypertonia may be present and this may be replaced by the intermittent spasms of athetosis. Involuntary choreiform movements may set in later, and deafness is also common. Mental defect is gross in some cases. In others a good level of intelligence is preserved though often masked by motor and sensory disabilities. The manifestations of $R h$ sensitization in mental defectives have been studied by Crome, Kirman, and Marrs (in preparation). Their findings correspond, on the whole, with those of other workers, a number of cases presenting a similar picture with athetosis, deafness, and a relatively well preserved mental capacity, though in other cases damage appears to be more extensive, even to the extent of complete idiocy.

These clinical manifestations are commonly regarded as being mainly "extrapyramidal", produced by lesions in the basal ganglia, viz., the globus pallidus and corpus Luysii. Such lesions have, in fact, been found in most of the recorded cases and given special prominence. Many of the authors have mentioned, however, the occurrence of other widely scattered abnormalities in the central nervous system. It is, indeed, possible that preoccupation with the readily detectable abnormalities in the basal ganglia has tended to obscure the more elusive widespread lesions in other areas, particularly in the cerebral cortex.

Knowledge of the structural changes caused by $\mathrm{Rh}$ sensitization rests, on the one hand, upon a large number of observations in patients dying in the neonatal period with hydrops foetalis or, more commonly, icterus gravis, and, on the other hand, on a small total of 17 morphological descriptions of cases of established residual kernicterus, some of which were of doubtful aetiology.

The structural changes found in the early fatal cases of $\mathrm{Rh}$ sensitization are characterized by generalized jaundice with staining by bilirubin of certain focal areas of the grey matter of the central nervous system, a blood picture marked by erythroblastosis and haemolysis, and some less constant findings in other organs such as persistence of haemopoietic foci in the liver and spleen, increase in size and weight of the liver and spleen, and the presence of iron-containing pigment and bilirubin in these organs (Bessis, 1946). The distribution of the stained foci in the central nervous system is very variable. Becker and Vogel (1948) have reviewed this problem well and supplied the following table of incidence in their own series : basal ganglia, 32 ; cerebellum, 25 ; medulla, 24; pallium, including hippocampus, 24 ; thalamus, 19 ; substantia nigra, 18 ; fourth ventricle, 18 ; meninges, 16 ; midbrain, 11 ; spinal cord, 10 ; ependyma, 9 ; hypothalamus, 8 ; choroid plexus, 7 ; epithalamus, 3 ; tela choroidea, 3 ; pons, 1 . The histological changes in these cases of acute kernicterus have been inconstant. The wide gradation of degenerative processes in the nerve cells throughout the nervous system has been stressed by Bertrand (1946), who referred also to the considerable loss of nerve cells in the cerebral cortex.

It is probable that those infants who survive to develop neurological sequelae of residual kernicterus have similar, even if less marked, structural changes in the acute stages, because of the similarity of the clinical and laboratory features in the two groups of cases. The nuclear staining fades fairly rapidly and is usually absent after the first few weeks, but longer duration permits the appearance of later stages of other possible lesions. The recorded structural nervous changes in such cases are given in Table I. 
TABLE I

CASES OF Rh FACTOR SENSITIZATION RECORDED IN THE LITERATURE

\begin{tabular}{|c|c|c|c|c|}
\hline Case & Author & Age & Chief Clinical Features & Structural Changes \\
\hline 1 & $\begin{array}{l}\text { Hoffmann and } \\
\text { Hausmann } \\
(1926)\end{array}$ & $3 \frac{1}{2}$ months & $\begin{array}{l}\text { Icterus at } 4 \text { days, twitching, rota- } \\
\text { tion of eyes, spasm of limbs, } \\
\text { hypertonia, opisthotonos }\end{array}$ & $\begin{array}{l}\text { Persistence of yellowish tinge in basal ganglia ; other changes only } \\
\text { microscopical: perivascular round-cell infiltration in basal } \\
\text { ganglia and hippocampus; no definite nerve-cell changes ; } \\
\text { haemosiderosis of the liver }\end{array}$ \\
\hline 2 & $\begin{array}{l}\text { Burghard and } \\
\text { Schleussing }\end{array}$ & 5 months & $\begin{array}{l}\text { Neonatal jaundice, yellow C.S.F., } \\
\text { convulsions, opisthotonos at } 5 \\
\text { days, hypertonia, early optic } \\
\text { atrophy, development of } \\
\text { generalized oedema, grimacing, } \\
\text { squint, profuse sweating }\end{array}$ & $\begin{array}{l}\text { Yellowish-grey staining of grey matter in pallidum, corpus Luysii, } \\
\text { and Ammon's horn, lesser staining in other parts ; some focal } \\
\text { softening of white matter in both hemispheres; destruction of } \\
\text { nerve cells with proliferation of glial cells, especially in hippo- } \\
\text { campus }\end{array}$ \\
\hline 3 & $\begin{array}{l}\text { de Lange } \\
(1934)\end{array}$ & 6 months & $\begin{array}{l}\text { Neonatal jaundice, petit mal, } \\
\text { hypertonia, opisthotonos, failure } \\
\text { of development }\end{array}$ & $\begin{array}{l}\text { Only basal ganglia examined. Lack of vertical striation in globus } \\
\text { pallidus; loss of nerve cells in caudate nucleus, globus pallidus, } \\
\text { and putamen; poor staining of myelin in globus pallidus and } \\
\text { corpus Luysii }\end{array}$ \\
\hline 4 & $\begin{array}{l}\text { Zimmerman } \\
\text { and Yannet } \\
\quad(1935)\end{array}$ & 3 years & $\begin{array}{l}5 \text { weeks premature, icterus gravis, } \\
\text { rigidity, opisthotonos, optic } \\
\text { atrophy after } 5 \text { months, athe- } \\
\text { tosis, mental retardation }\end{array}$ & $\begin{array}{l}\text { Demyelination of optic nerves, white matter around posterior horns } \\
\text { of lateral ventricles, peripheral part of spinal cord; fascia } \\
\text { dentata and endplate of lamina parietalis of hippocampus } \\
\text { destroyed; loss of large nerve cells in corpus striatum and } \\
\text { globus pallidus; absence of myelinated fibres in globus pallidus; } \\
\text { corpus Luysii almost completely disappeared; paucity of nerve } \\
\text { cells in red nuclei }\end{array}$ \\
\hline 5 & de Lange & $7 \mathfrak{3}$ months & $\begin{array}{l}\text { One of twins both of whom had } \\
\text { neonatal jaundice without } \\
\text { erythroblastosis; hypertonia, } \\
\text { rickets, retarded development }\end{array}$ & $\begin{array}{l}\text { Yellow staining of flocculus, inferior olives, floor of fourth ventricle, } \\
\text { Ammon's horn, thalamus, putamen, globus pallidus, and } \\
\text { habenular nucleus ; degeneration of nerve cells in inferior olives, } \\
\text { globus pallidus, and putamen ; iron and bile pigment in liver; } \\
\text { cellular proliferation in portal tracts }\end{array}$ \\
\hline 6 & $\begin{array}{l}\text { de Lange } \\
(1936)\end{array}$ & 6 months & $\begin{array}{l}\text { Neonatal jaundice, slight enlarge- } \\
\text { ment of liver and spleen, hyper- } \\
\text { tonia, head retraction, rigidity }\end{array}$ & $\begin{array}{l}\text { Absent striation of globus pallidus with loss of nerve cells; poor } \\
\text { staining of myelin in globus pallidus and corpus Luysii; slight } \\
\text { loss of cells in dentate nucleus : some deficiency of myelin in } \\
\text { frontal and temporal lobes; corpus callosum and anterior } \\
\text { commissure small; certain cytoarchitectonic abnormalities of } \\
\text { cerebral cortex }\end{array}$ \\
\hline 7 & \multirow{2}{*}{$\begin{array}{l}\text { Biemond and } \\
\text { van Creveld } \\
(1937)\end{array}$} & 3 months & $\begin{array}{l}\text { Neonatal jaundice and umbilical } \\
\text { sepsis, rigidity, opisthotonos }\end{array}$ & $\begin{array}{l}\text { Absent striation of globus pallidus; demyelination of globus } \\
\text { pallidus and corpus Luysii; loss of nerve cells and gliosis in } \\
\text { demyelinated areas; corpus callosum and fornices small }\end{array}$ \\
\hline 8 & & 4 months & $\begin{array}{l}\text { Neonatal jaundice and umbilical } \\
\text { sepsis, slight anaemia, extra- } \\
\text { pyramidal signs with rigidity } \\
\text { and opisthotonos }\end{array}$ & $\begin{array}{l}\text { Slight yellow staining of globus pallidus and corpus Luysii } \\
\text { absent striation of globus pallidus: marked demyelination of } \\
\text { globus pallidus and corpus Luysii with loss of nerve cells } \\
\text { corpus callosum and fornices small }\end{array}$ \\
\hline 9 & $\begin{array}{l}\text { Westrienen } \\
\text { and de Lange } \\
(1937-38)\end{array}$ & $\begin{array}{l}\text { About } \\
1 \text { year }\end{array}$ & $\begin{array}{l}\text { Icterus gravis, convulsions, opis- } \\
\text { thotonos, profuse sweating, } \\
\text { clasp-knife rigidity }\end{array}$ & $\begin{array}{l}\text { Blurred striation of globus pallidus with some shrinking of nervect } \\
\text { cells and proliferation of glial cells ; greater proliferation of glia } \\
\text { in striatum ; subthalamic nucleus small; poor staining of myelin } \\
\text { in globus pallidus }\end{array}$ \\
\hline 10 & $\underset{(1938)}{\text { Zimmerman }}$ & 11 months & $\begin{array}{l}\text { Neonatal jaundice, spasticity, head } \\
\text { retraction, convulsions }\end{array}$ & $\begin{array}{l}\text { Focal loss of nerve cells in caudate nucleus, putamen, dentate } \\
\text { nucleus, inferior olives, and cerebral cortex }\end{array}$ \\
\hline 11 & \multirow{2}{*}{$\begin{array}{l}\text { FitzGerald, } \\
\text { Greenfield, } \\
\text { and Kounine } \\
\quad(1939)\end{array}$} & $4 \frac{1}{2}$ months & Neonatal jaundice & $\begin{array}{l}\text { Bilateral sclerosis of globus pallidus with an almost total disappear- } \\
\text { ance of nerve cells; considerable loss of nerve cells in corpus } \\
\text { Luysii with dense fibrous gliosis; Ammon's horn and fascia } \\
\text { dentata sclerosed }\end{array}$ \\
\hline 12 & & 1 year & Neonatal jaundice & $\begin{array}{l}\text { Basal ganglia, particularly the globus pallidus, shrunken and white; } \\
\text { moderate cell loss in globus pallidus with poor staining of myelin } \\
\text { corpus Luysii sclerosed; appearance of cortical nerve cells } \\
\text { suggestive of lack of differentiation }\end{array}$ \\
\hline 13 & $\begin{array}{l}\text { Sobel and } \\
\text { Zucker } \\
(1940)\end{array}$ & $4 \frac{1}{2}$ years & $\begin{array}{l}\text { Neonatal jaundice, erythroblas- } \\
\text { tosis and anaemia, opisthotonos, } \\
\text { spasticity, and choreo-athetosis }\end{array}$ & $\begin{array}{l}\text { Moderate dilatation of ventricles; poor staining of myelin in } \\
\text { globus pallidus and corpus Luysii ; loss of myelin in pyramids ; } \\
\text { decrease in number of nerve cells in layers III and IV of cerebral } \\
\text { cortex with proliferation of glia in cerebrum and diencephalon }\end{array}$ \\
\hline 14 & $\begin{array}{l}\text { van Bogaert } \\
(1947)\end{array}$ & $2 \frac{1}{2}$ years & $\begin{array}{l}\text { Neonatal jaundice, opisthotonos, } \\
\text { "decerebrate" position of } \\
\text { upper limbs, development of } \\
\text { choreo-athetosis }\end{array}$ & $\begin{array}{l}\text { Atrophy of corpus Luysii and, to a lesser degree, of globus pallidus ; } \\
\text { slight degenerative changes in cerebral cortex }\end{array}$ \\
\hline 15 & $\underset{(1948)}{\text { McLardy }}$ & 2 years & 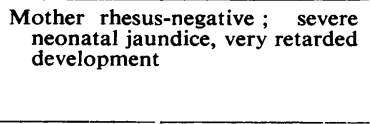 & $\begin{array}{l}\text { Bilateral shrinking of globus pallidus with almost total demyelination } \\
\text { and fibrous gliosis; conspicuous demyelination of large radial } \\
\text { bundles of putamen and caudate nucleus ; complete degeneration } \\
\text { of corpus Luysii and degeneration of nerve cells in pyramidal } \\
\text { layer and fascia dentata of hippocampus }\end{array}$ \\
\hline 16 & $\begin{array}{c}\text { Mann and } \\
\text { Courville } \\
(1948)\end{array}$ & 7 months & Neonatal jaundice & $\begin{array}{l}\text { Paucity of nerve cells in dentate nucleus, putamen, and globus } \\
\text { pallidus ; occasional perivascular sclerosis with increase of glia ; } \\
\text { many cells in substantia nigra vacuolated with indistinct outlines }\end{array}$ \\
\hline 17 & $\begin{array}{l}\text { Christensen } \\
\text { and } \\
\text { Vestergaard } \\
\text { (1949) }\end{array}$ & 22 years & Mental defective & $\begin{array}{l}\text { Internal hydrocephalus ; moderate atrophy of basal ganglia ; } \\
\text { peculiar microscopical yellowish pigment ; some degeneration } \\
\text { of nerve cells in cerebral cortex and Ammon's horn; softening in } \\
\text { white matter }\end{array}$ \\
\hline
\end{tabular}


Most of the cases listed in Table I were examined before modern serological methods made diagnosis of rhesus factor sensitization possible. It is worth while therefore to record the following two further cases in which serological and clinical studies left little doubt as to rhesus factor incompatibility, icterus gravis neonatorum, and, presumably, kernicterus. Both occurred in a series of 140 consecutive necropsies of low-grade mental defectives at the Fountain Hospital.

In a third case, the issue of an incestuous union of brother and sister with rhesus factor incompatibility, neonatal jaundice and erythroblastosis foetalis were followed by complete idiocy, the pathological findings at necropsy being generalized lipoidosis occupying an intermediate position between TaySachs and Niemann-Pick disease. This case presents a special problem and will be reported separately.

\section{Case Reports}

Case 1. - The patient was the second son of a rhesusnegative mother and a rhesus-positive father. There is no history of mental defect in the family. The mother was found to have $\mathrm{Rh}$ antibodies at about the thirtyseventh week of her first pregnancy, which preceded the second by two years, but the elder child's neonatal jaundice was mild, calling for no treatment, and his further development uneventful.

The mother's antibody titre rose to 1 in 1,000 some two months before the patient's birth and labour was induced at 36 weeks. The infant weighed $6 \mathrm{lb}$., his cord haemoglobin being $64 \%$ with a positive Coombs test. He was given an exchange transfusion by the umbilical vein, after which blood bilirubin was estimated at $9 \mathrm{mg}$. per $100 \mathrm{ml}$. The jaundice deepened the following day and another blood transfusion was given. After that it remained unchanged for some days, and gradually faded by the end of the first month. Fluctuating spasticity of the limbs appeared at the age of 2 months. At 5 months it was thought that he could hear and see, his head control was fairly good, and at 7 months he could grip things feebly and had his first tooth. A month later he was able to raise his hand to the mouth. His general health was reasonably good and weight gain satisfactory. At 10 months the mother sought further advice for the child's frequent prolonged crying fits.

At 15 months he was admitted to the Fountain Hospital as a temporary case. He was then accessible and cheerful, smiled when stroked, chuckled when tickled but made no sounds resembling speech. He smiled responsively to the ringing of a bell and so was not deaf. He followed objects with his eyes but made no attempt to reach for them; he had a good grasp in either hand. He was intermittently rigid with occasional tremor in both arms and could not sit unsupported. His teeth were poor and yellowish and he had a double internal squint. The right side of the chest was flattened and he had an umbilical hernia. His developmental level was assessed at 3 months on the Vineland maturity scale, but this result was thought to be due in part to a specific motor handicap rather than to general retardation. A few weeks after admission he developed hyperpyrexia, $105^{\circ} \mathrm{F}$., had generalized twitching and cyanosis, and died some hours later.

Pathological Findings.-Kyphoscoliosis and marked pigeon chest were the only visible deformities at necropsy. The subject weighed $9 \mathrm{~kg}$., with height $90 \mathrm{~cm}$. and head circumference $46.4 \mathrm{~cm}$. The testes were in the inguinal canals, and the lungs showed a varied pattern of congestion, early consolidation, and lobular collapse, these changes being confirmed microscopically. The portal tracts of the liver contained a moderate amount of cellular exudate consisting chiefly of lymphocytes with a few polymorphs and plasma cells.

The only surface abnormality of the brain $(1,050 \mathrm{~g}$.) was congestion of the superficial veins. Coronal sections of the formalinized material showed reduction in size with absence of medullary pallidal lamination and slight discoloration of the globus pallidus anteriorly.

Coronal blocks of the frontal, parietal, temporal, and occipital lobes, the cerebellum, midbrain, pons, and medulla, together with representative levels of the spinal cord, were embedded in celloidin. Serial sections were cut of the basal ganglia on the left side. The usual neurological and general stains were employed, frozen sections being also used for scarlet $\mathbf{R}$ and KulschitskyPal staining as well as for silver impregnation methods.

The two conspicuous structural changes were sparseness of cells in the superficial layers of the cerebral cortex and abnormality of the globus pallidus.

Cells were sparse in all areas of the cortex, being, possibly, more marked in the frontal and occipital lobes (Fig. 1). This sparseness was easily detectable in layers

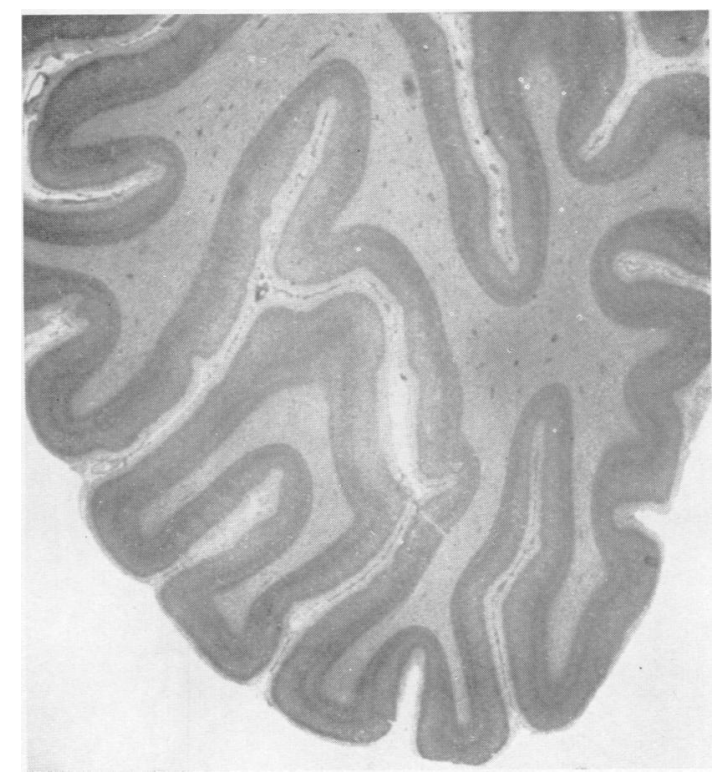

FIG. 1.-Occipital lobe : sparseness of nerve cells in superficial layers of cortex. Cresyl violet. $\times 23$. 


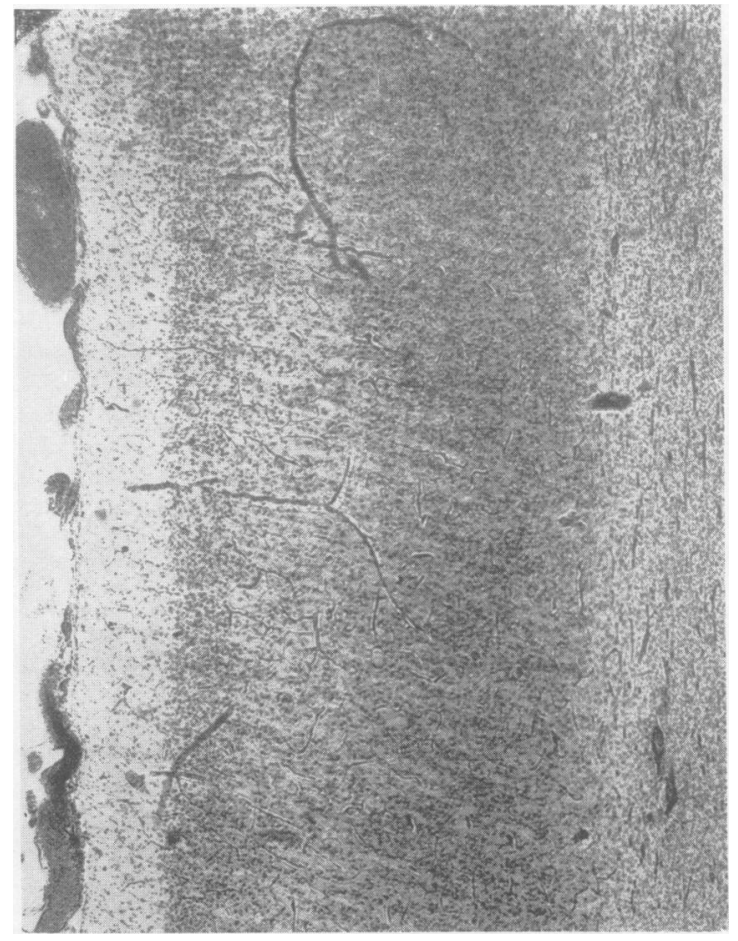

FIG. 2.-Area 8 : loss of cells in layers II and III. Cresyl violet. $\times 27$.

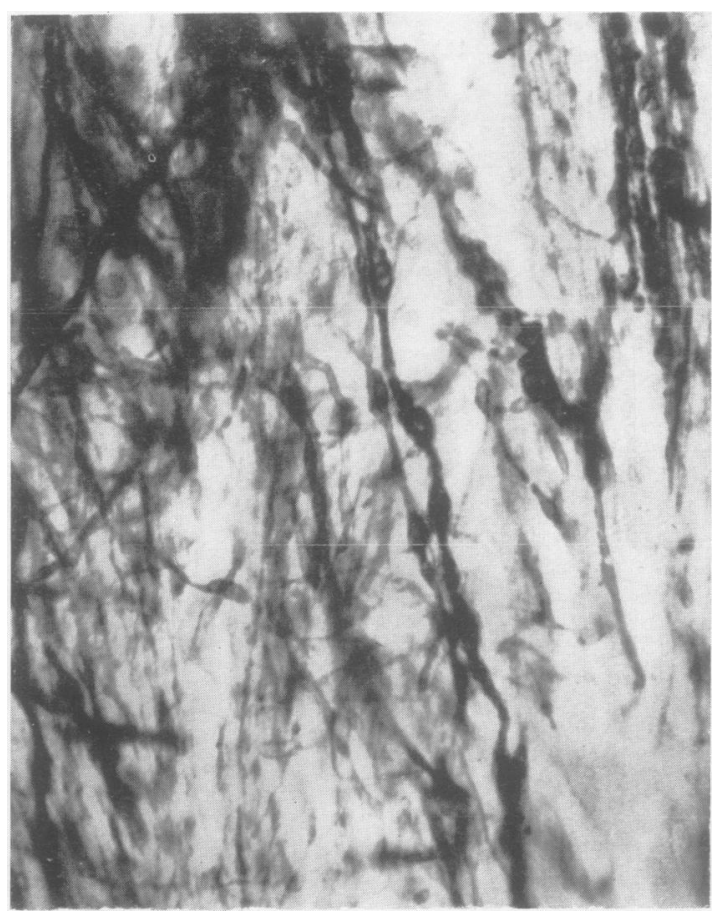

Fig. 4.-Globus pallidus : degeneration of myelin sheaths. Kulschitsky-Pal. $\times 550$.

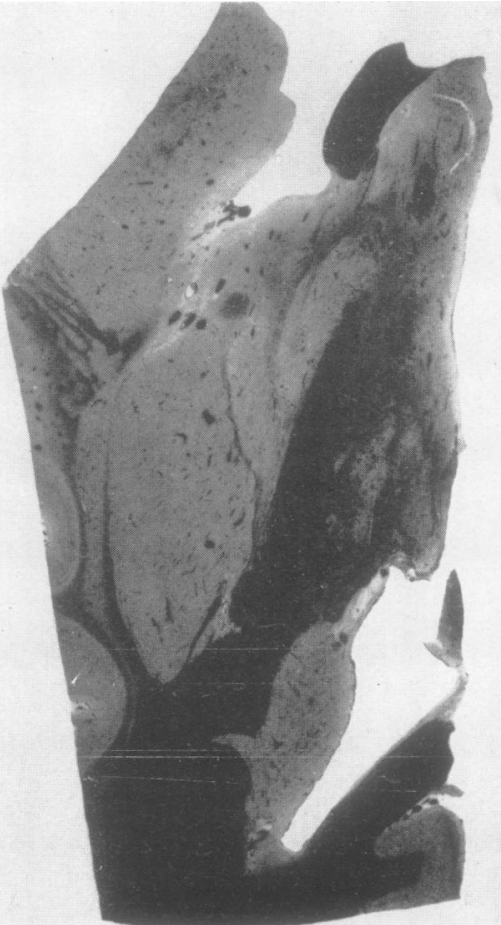

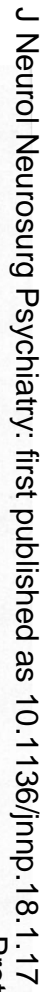

FIG. 3.-Basal ganglia: pallor of myelin in globus pallidus. $\stackrel{\vec{\Phi}}{\circ}$ 은 Heidenhain. $\times 2 \frac{1}{2}$.

远

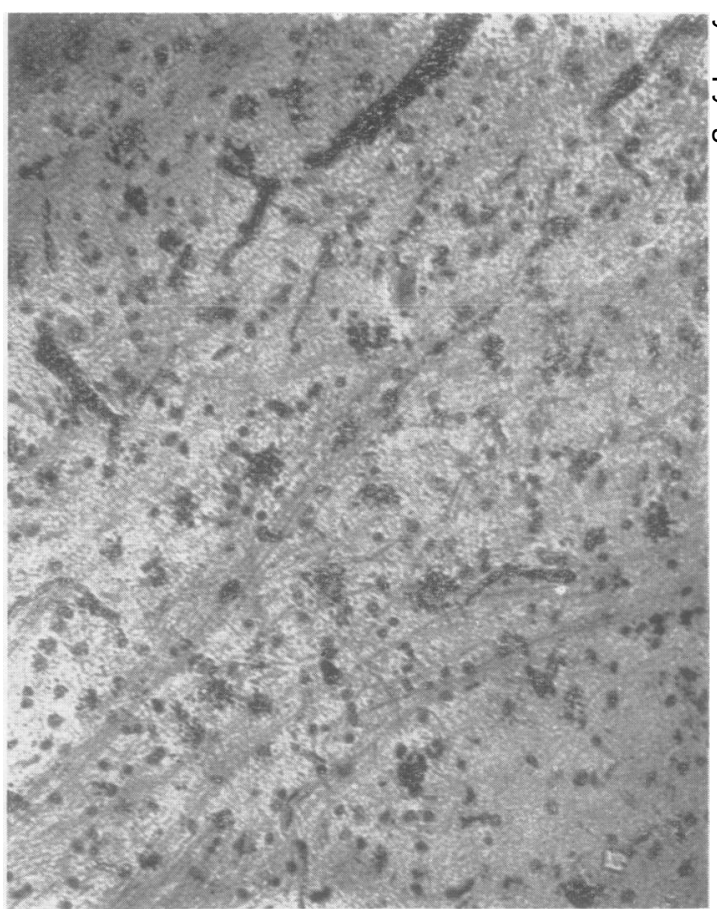

व $\mathbb{Q}$

ᄋి ำ

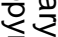
을 을

胥

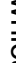

西

$\stackrel{8}{8}$

贾

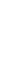

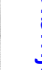

.

Fig. 5.-Globus pallidus : numerous particles of neutral fat. Herxheimer. $\times 160$. 
II and III (Fig. 2) but was probably also present in the deeper ones. The loss of cortical nerve cells was associated with degenerative changes in the remaining ones. These changes were not confined, however, to the cortex and will therefore be treated separately below.

The myelin in the anterior part of the globus pallidus was abnormally pale in sections stained by the Heidenhain and Kulschitsky-Pal methods (Fig. 3). There was also a conspicuous deficiency in the myelination of the large radial bundles in the putamen. Higher magnifications of the globus pallidus sections showed myelin sheaths in various stages of degeneration and breakdown (Fig. 4), consisting of tortuosity, focal ballooning, varicosity, uneven staining, and beading. Similar appearances were present in other parts of the nervous system, those in the globus pallidus being, however, more pronounced. Sections of this area stained by the Herxheimer method showed a much larger amount of neutral fat than in other places (Fig. 5). It was partly contained in compound granular corpuscles and endothelial capillary cells, and partly lay free in the tissue and in perivascular spaces. Some fibrous gliosis could also be demonstrated in the globus pallidus by the Holzer and the silver impregnation methods. The number of nerve cells was, however, only slightly reduced.

A small amount of cellular exudate was present in the meninges, consisting chiefly of lymphocytes and some macrophages containing yellow granular pigment.

Some foci of dense fibrous gliosis spreading from the surface to laminae I and II were found in the cerebral cortex; this was generalized in the hippocampus. Glial cells, consisting of microglia and fibrillary astrocytes, were slightly increased in number throughout the grey matter of the nervous system.

Nerve cells in the cerebral cortex and elsewhere stained very unevenly, some being hyper- and others hypo-chromatic. Their outlines were often irregular and indistinct with the cytoplasm vacuolated. Nissl substance was absent from all but the largest of them, and in those it tended to be broken into small particles and displaced peripherally. Many "ghost" forms could be seen.

A small amount of neutral fat was visible in all parts of the central nervous system, chiefly around capillaries, either free or in compound granular corpuscles and endothelial cells.

No other abnormality was found in the basal ganglia. The thalamic and subthalamic nuclei were, in particular, free from demonstrable change.

The only other noteworthy features were dense mural fibrous gliosis affecting the entire ventricular system and a semicircular layer of spongy degeneration situated midway between the outer pyramidal cells and the fascia dentata of the hippocampus.

Case 2.-The patient was the fourth child of a rhesusnegative mother and a rhesus-positive father. Two of the siblings, seven and five years older, were normal, the third died with neonatal jaundice three days after delivery, while the fifth and last pregnancy was terminated artificially. The mother had had a kidney removed before marriage and suffered from whooping cough during the patient's gestation. She and her husband were otherwise in good health. There is no history of mental defect in the family.

The pregnancy ended with a breech delivery about three weeks before term. The baby, weighing $1.6 \mathrm{~kg}$., was limp and cried feebly. She was not immediately jaundiced, but Coombs's test was positive with haemoglobin $88 \%$ and nucleated red cells 29 per 100 W.B.C. A replacement transfusion was given the same day.

Jaundice appeared on the third day, when haemoglobin was $94 \%$. On the sixth day twitching of limbs was observed, the head was retracted, the limbs spastic, and the body rigid. A lumbar puncture performed the following day yielded bile-stained fluid but no other abnormality. At 20 days, she had an attack of cyanosis with apnoea during a feed and was resuscitated with oxygen and coramine. She remained in poor general condition for a few days, having irregular respiration and feeding difficulty calling for tube feeding. After that she became anaemic with haemoglobin $68 \%$ on the twenty-second day and $48 \%$ on the thirty-third day. Examination of the bone marrow showed cellular active degeneration of normoblastic type with large numbers of primitive R.B.C.s, including pro-erythroblasts. A transfusion with $30 \mathrm{ml}$. of packed red cells was given at this stage, and two further transfusions with $38 \mathrm{ml}$. and $65 \mathrm{ml}$. of packed cells repeated at weekly intervals. The patient's general condition remained satisfactory, the haemoglobin rose to $80 \%$, she gained weight, and was discharged at 2 months, taking the breast and supplementary feeds.

When seen six or seven months later she weighed $7 \mathrm{~kg}$. and her mother complained that she was difficult to manage and cried frequently. She could not sit up. She was at that time spastic with choreo-athetotic movements. At 13 months she was seen again, and institutional treatment was recommended on account of her restlessness, poor sleep, and trouble at home.

On admission to the Fountain Hospital at 19 months she weighed $8 \mathrm{~kg}$., with a head circumference of $41 \mathrm{~cm}$. She could not talk, walk, sit, or do anything for herself. When an object was placed in her left hand she retained her grasp on it, but when anything was placed in her right hand she dropped it limply. She lay all the time in a position of marked opisthotonos and displayed very little spontaneous activity. She had generalized rigidity, athetoid movements, and a variable internal squint.

When a bell was rung, she stirred slightly and opened her eyes. She focused on brightly coloured objects and her eyes followed a pencil. She even made some effort to grasp objects with her right hand, but was handicapped in this by her incoordinated movements. She appeared to be of idiot level of intelligence.

Within three days of admission she developed bronchopneumonia, but recovered with penicillin and streptomycin treatment. The usual laboratory investigations, such as the Mantoux test, Wassermann reaction, blood and C.S.F. counts, were done, but added nothing significant. Her and her parents' blood groups are shown in Table II.

As both the father and patient were $R_{2} r$ (positive) while the mother was $R h$-negative and had anti-D in 
TABLE II

BLOOD GROUPS OF CASE 2 AND HER PARENTS

\begin{tabular}{|c|c|c|c|c|c|c|c|c|c|c|c|}
\hline & & & ABO & MNS & $\mathbf{P}$ & $\mathbf{R h}$ & Lutheran & Kell & Lewis & Duffy & Kidd \\
\hline Father & .. & .. & $\mathbf{O}$ & MNSs & $\mathbf{P}-$ & $\mathbf{R}_{\mathbf{2}} \mathbf{r}$ & $\mathrm{Lu}(\mathrm{a}+\mathbf{)}$ & K- & $\overline{\operatorname{Le}(a-b+)}$ & $F y(a+)$ & $\mathrm{Jk}^{\mathrm{k}}(\mathrm{a}+1)$ \\
\hline Mother & .. & .. & o & MNSs & $\mathbf{P}+$ & $\mathbf{r r}$ & $\mathbf{L u}(\mathrm{a}-)$ & $\mathbf{K}-$ & $\operatorname{Le}(a-b+)$ & $F y(a-)$ & $\mathbf{J k}(\mathrm{a}-)$ \\
\hline Patient & .. & .. & 0 & MNSs & $\mathbf{P}-$ & $\mathbf{R}_{2} \mathbf{r}$ & $\mathbf{L u}(\mathrm{a}+)$ & $\mathbf{K}-$ & $\operatorname{Le}(a-b+)$ & Fy(a-) & $\mathbf{j} \mathbf{k}(\mathbf{a}+)$ \\
\hline
\end{tabular}

her serum, the patient was probably a case of kernicterus due to rhesus incompatibility.

A month after admission to the Fountain Hospital, she went into status epilepticus, and died, in spite of all attempts to stop the convulsions, $\mathbf{3 0}$ hours later.

Pathological Findings.- Nothing noteworthy was found on naked-eye inspection in any organ other than the lungs, which showed some petechial pleural haemorrhages, pulmonary oedema, and congestion with small areas of lobular collapse in the lower lobes. Microscopical examination added nothing to the pulmonary findings.

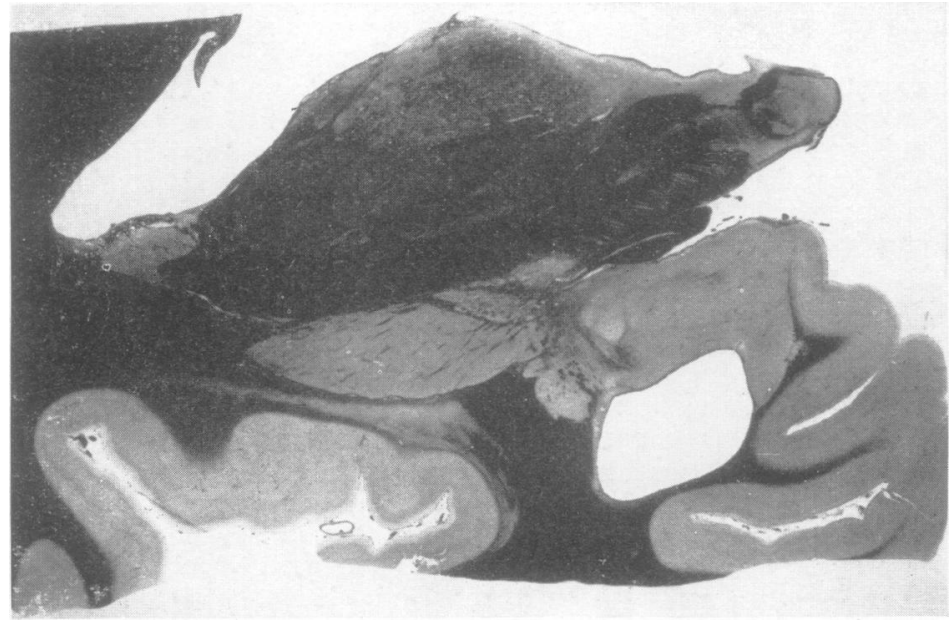

FIG. 6.-Pallor of myelin in globus pallidus. Heidenhain. $\times 2 \Varangle$. cortical cells was, possibly, greater in the present case, while changes in the globus pallidus affected its components differently. The myelin was only slightly paler than normally (Fig. 6), although it presented many features of breakdown on higher magnification. The number of nerve cells in it was not appreciably reduced, while fibrous gliosis was more marked in the Holzer sections than in the first case. The corpus Luysii was, as mentioned above, somewhat reduced in size and the density of nerve cells in it slightly diminished.

Deficiency in the large radial bundles in the putamen was another mark of similarity with the first case.

The meninges showed a slight increase in collagenous connective tissue with a moderate cellular exudate of lymphocytes and fewero polymorphs. A uniform margina $\overline{\mathrm{D}}$ fibrous gliosis extended over the whole of the cerebral cortex and brain-stem $\bar{D}$ The number of glial cells, astrocytes $\bigcirc$ and microglia was slightly increaseck throughout the grey matter. Some of the microglial cells were enlarged while others were phagocytic, containing, as in Case 1, a small quantity of neutrab fat. The astrocytes were fibrillary in type.

Most of the nerve cells throughout the entire nervous system exhibited some degree of degenerative change. Those of the cerebral cortex presented mainly chromatolysis, shrinking, and transitional stages of homogenization with many "ghost" forms. Many of the cells in the subcortical centres showed similar changes, although these were less
uniform. There was some focal loss in the Purkinje cerebellar cells, with feeble staining and swelling of the cytoplasm and nucleus in the remaining ones. Cells in the dentate and inferior olivary nuclei were also somewhat reduced in number, with many of the remaining ones showing degenerative change. Some of the large multipolar cells of the cranial nerve nuclei and anterior horns of the spinal cord showed chromatolysis and swelling of cytoplasm, while others were shrunken and their nuclei pyknotic.

Mural fibrous gliosis was present throughout the ventricular system. Scattered in the substance of the brain, spinal cord, and in the subarachnoid space were many small terminal haemorrhages with no fibrin or reactive changes around them.
The liver showed a slightly increased amount of

The brain was small, $819 \mathrm{~g}$. (normal, $1,050 \mathrm{~g}$.), and the soft meninges were somewhat opaque, especially over the Sylvian fissure. The ventricular system was slightly dilated. The coronal blocks of the brain showed a barely perceptible bluish-brown discoloration of the globus pallidus and lack of definition in its outlines. The size and their outlines were somewhat indistinct.

Methods of histological examination of the central nervous system were as in Case 1 above.

The two main structural changes were closely similar to those of the first case : reduction in the number of cells in the superficial layers of the cerebral cortex and abnormality of the globus pallidus. The sparseness of

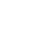




\section{Discussion}

The two cases of the series correspond fairly closely with those recorded by earlier workers. The morphological changes in both of them were characterized by widespread loss of nerve cells in the cerebral cortex and by a more localized change in the globus pallidus. The significance of all the enumerated degenerative lesions in the nerve cells cannot be fully assessed ; some of them may well have been caused by the terminal illness, especially in Case 2 marked by prolonged status epilepticus, others by post-mortem autolysis, and the remainder by the continuing effect of the basic pathogenetic factors responsible for the brunt of the damage.

The two main morphological changes are not specific for Rh sensitization. Loss of cortical nerve cells with ensuing laminar rarefaction is a common finding in the brain of low-grade mental defectives of many nosological groups. The globus pallidus is also a common seat of pathological processes, particularly those associated with anoxic states. It is true that cortical damage has not been mentioned in all of the previously recorded cases of residual kernicterus, but the reason for this may well have been the relative difficulty of its certain recognition, associated with the importance customarily attached to lesions in basal ganglia in extrapyramidal syndromes. It seems likely that it may be observed more frequently in similar cases if attention is paid to it in future studies.

Changes in the corpus Luysii were observed in Case 2 only. Deficiency in the large radial bundles of the putamen was present in Cases 1 and 2, but has been previously noted only by McLardy (1948).

It may be concluded, therefore, that the structural nervous changes in $\mathrm{Rh}$ sensitization are, like those of the acute kernicterus preceding it, widespread. They are characterized, in particular, by loss of nerve cells in the cerebral cortex and reduction in size, demyelination, and fibrous gliosis in the globus pallidus, and, more rarely, in the corpus Luysii.

\section{Summary}

The structural nervous changes in the recorded cases of neurological disease following severe jaundice of the newborn are reviewed and tabulated. A clinical and morbid-anatomical account is given of two further cases with serologically established rhesus factor incompatibility, neonatal jaundice, and erythroblastosis, both of which recovered from the initial acute condition to develop neurological disease. Changes in them were characterized by widespread cellular loss in the cerebral cortex with more focal lesions in the globus pallidus and, in one case, the corpus Luysii.

I am greatly indebted to my lay and medical colleagues at the Fountain Hospital for their cooperation and for access to case records. I am grateful to Dr. R. R. Race, F.R.S., for the results of blood group investigations.

\section{REFERENCES}

Becker, P. F. L., and Vogel, P. (1948). J. Neuropath., 7, 190.

Bertrand, I. (1946). Rev. Hémat., 1, 399.

Bessis, M. (1946). Ibid., 1, 300.

Biemond, A., and Creveld, S. van (1937). Arch. Dis. Childh., 12, 173.

Bogaert, L. van (1947). Ann. paediat., Basel, 168, 57.

Burghard, E., and Schleussing, H. (1933). Klin. Wschr., 12, 1526.

Christensen, E., and Vestergaard, E. (1949). Acta psychiat. neurol. scand., 24, 363.

Evans, P. R., and Polani, P. E. (1950). Quart. J. Med. n.s., 19, 129.

FitzGerald, G. M., Greenfield, J. G., and Kounine, B. (1939). Brain, 62, 292.

Hoffmann, W., and Hausmann, M. (1926). Mschr. Kinderheilk., 33, 193.

Lange, C. de (1934). Jb. Kinderheilk., 142, 255.

(1935). Ibid., 145, 273.

- (1936). Rev. franç. Pédiat., 12, 793.

McLardy, T. (1948). Brain, 71, 290.

Mann, L. B., and Courville, C. B. (1948). Bull. Los Angeles neurol. Soc., 13, 69

Pentschew, A. (1948). Arch. Psychiat. Nervenkr., 180, 118.

Pickles, M. M. (1949). Haemolytic Disease of the Newborn. Blackwell, Oxford.

Sobel, I. P., and Zucker, J. M. (1940). J. Pediat., 16, 445.

Westrienen, A. van, and Lange, C. de (1937-38). Jb. Kinderheilk., 150, 257.

Zimmerman, H. M. (1938). J. Pediat., 13, 878.

-, and Yannet, H. (1935). Amer. J. Dis. Child., 49, 418. 